\title{
A Review of Steelmaking Technologies
}

\author{
Sudipto Shekhor Mondol \\ Department of Mechanical Engineering, Heritage Institute of Technology
}

\begin{abstract}
Steelmaking is the method of developing steel from iron ore (usually haematite) and scrap. The impurities such as nitrogen, sulphur, silicon, phosphorus and excess carbon are separated out from the raw iron and alloying elements such as nickel, manganese, vanadium, molybdenum and chromium are added to impart different properties to steel. The technology of steelmaking has made great advancements with time. This paper describes the modern technologies used in a steel plant while reviewing the conventional processes as well.
\end{abstract}

Keywords: Steelmaking, Steel, Blast furnace, Open hearth furnace, Darva glass

\section{Introduction}

Steel is one of the strongest materials on earth. It has changed the course of our history, shaping our civilisation and the way we live. But today scientists are reengineering steel's molecular structure creating new forms with the potential to build higher, further and stronger than the World has ever seen. Steel is an alloy of iron and carbon. It is the world's most useful and inexpensive metal. Steel is made of crystals and the dislocations inside the crystals helps to deform. Steel is tough and has high tensile and compression strength. Steel is divided up into a patchwork and each individual patch is a crystal. Inside these crystals are iron atoms which are arranged in a regular way. If we zoom out we can see the crystals disrupted (as shown in the Fig. 1).

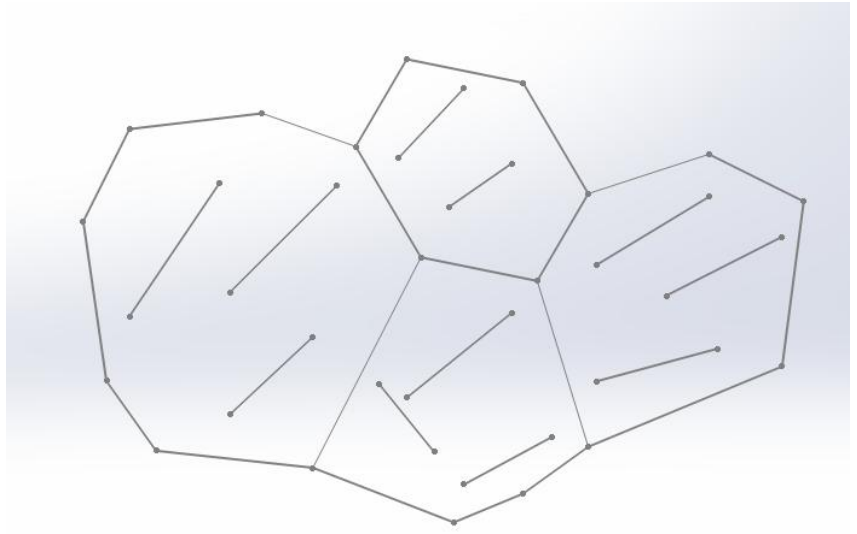

Figure 1: Schematic diagram of dislocations inside steel crystal

These dislocations are what make steel crystal so special because they can move. When they move they change the shape of the crystal and thus they change the shape of steel. Thus, it finds its various applications like in construction, automobile, food preservation, aircrafts, ships, utensils, etc.

\section{The Raw Materials}

\subsection{Iron ore}

Iron ore is found near the surface of the earth and open pit mining methods are used. Giant shovels scoop up huge bites of ore. The trucks are quickly loaded and the ore is on its way. Underground mining methods are also used.

\subsection{Limestone}

Rocks are blasted and the stones are transported to thesteel industry.

\subsection{Coke}

Bituminous or soft coal is converted into coke. This takes the place of charcoal previously used as fuel. The coal is first crushed and then heated in ovens until the moisture and volatile matter has been driven off. After all the by-products have been extracted from the non-volatile matter, the gas that remains can be used as fuel. After 16-24 hours the red hot coke is pushed out. It usually contains $91-92 \%$ Carbon.

\section{Blast Furnace}

The charge is fed into the blast furnace continuously. One ton of iron requires approximately two tons of iron ore, one ton of coke, half a ton of limestone and four tons of air. Hot blast stoves and powerful blowers which force huge amounts of preheated air into the furnace. Heating the air increases production and decreases fuel consumption. In striking contrast to primitive methods the modern blast furnaces are controlled scientifically.

Up through the mass of coke, iron ore and limestone is blown at roaring blast of preheated air.

$$
\begin{gathered}
\mathrm{C}(\mathrm{s})+\mathrm{O}_{2}(\mathrm{~g})->\mathrm{CO}_{2}(\mathrm{~g}) \\
\mathrm{CO}_{2}(\mathrm{~g})+\mathrm{C}(\mathrm{s})->2 \mathrm{CO}(\mathrm{g})
\end{gathered}
$$

At the top the temperature is about $300^{\circ} \mathrm{F}$ increasing at lower levels to a maximum of about $3300{ }^{\circ} \mathrm{F}$. As the charge heats the gases formed by the burning coke draw oxygen from the ore as it descends through the furnace leaving spongy metals. The charge descends through increasing heat until about $2000{ }^{\mathrm{O}} \mathrm{F}$ the spongy metals absorbs $3.5 \%$ carbon from the coke; continuing to descend about $2500{ }^{\mathrm{O}} \mathrm{F}$ the iron with the absorbed carbon melts.

$$
\mathrm{Fe}_{2} \mathrm{O}_{3}+3 \mathrm{CO}->2 \mathrm{Fe}+3 \mathrm{CO}_{2}(\mathrm{~g})
$$

The limestone combines with the earthy matter of the ore forming slag. The iron and slag form in molten globules like raindrops which trickle down through the burning coke. A pool of molten iron is formed at the bottom of the furnace. 


\section{International Journal of Science and Research (IJSR) \\ ISSN (Online): 2319-7064}

Index Copernicus Value (2013): 6.14 | Impact Factor (2014): 5.611

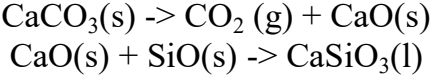

The slag floats on the iron and is collected from the furnace through a slag hole. Every four or five hours the tapping hole is opened and out rushes a glowing stream of molten iron.

\section{Bessemer Converter}

This technology was discovered by Henry Bessemer about 150 years ago and it was the first method in which steel can be produced on a large scale. The Bessemer process removes impurities from pig iron.

$$
\mathrm{Fe}+\mathrm{O}_{2}->2[\mathrm{FeO}]
$$

Silicon and manganese is oxidised first.

$$
\begin{gathered}
2[\mathrm{FeO}]+\mathrm{Si}->\mathrm{SiO}_{2} \\
{[\mathrm{Mn}]+[\mathrm{FeO}]->\mathrm{MnO}+\mathrm{Fe}}
\end{gathered}
$$

The carbon oxidation starts only after silicon and manganese is oxidised.

$$
\begin{gathered}
2 \mathrm{C}+\mathrm{O}_{2}->2 \mathrm{CO} \text { (Burns with a blue fame) } \\
\mathrm{CO}+[\mathrm{FeO}]->\{\mathrm{CO}\}+\mathrm{Fe} \\
\mathrm{MnO}+\mathrm{SiO}_{2}->\mathrm{MnSiO}_{3}(\mathrm{Slag})
\end{gathered}
$$

This technology is no longer used as it wastes a large amount of heat. Also $\mathrm{N}_{2}$ content of steel is high which makes the steel brittle. Also it is hard to maintain.

\section{Open Hearth Furnace}

The hot metals from the blast furnace is tapped into ladles. Iron must be further refined to become steel. Tailor-made steel can be produced in large quantities using this method. First, the limestone is dumped in the furnace. Limestone removes impurities from the steel. The furnace is then charged with a predetermined amount of scrap steel. As the scrap is already refined steel it's a helpful ingredient. Lastly, a huge overhead crane dumps huge ladle of hot metal as it comes from the blast furnace. The usual charge is about half scrap steel and half blast furnace iron.

An open hearth furnace consists of what might be described as an upstairs and a downstairs. Upstairs is the hearth in which the steel making materials are refined. Downstairs are heating chambers containing firebrick made in checker board pattern. One chamber for heating the fuel which may be oil, gas or oil and tar and another chamber for heating air.
The preheated air and fuel move upward and pass into the space above the hearth; combustion instantly takes place. Currents of flaming fuel sweep over the hot metal creating temperatures above $3000^{\circ} \mathrm{F}$. Excess carbon and impurities are burnt out.

$$
\begin{aligned}
& \mathrm{Si}+2 \mathrm{FeO}->\mathrm{SiO}_{2}+2 \mathrm{Fe} \\
& \mathrm{Mn}+\mathrm{FeO}->\mathrm{MnO}+\mathrm{Fe}
\end{aligned}
$$

The hot exhaust gases pass down to another set of checker chamber heating the bricks as they pass between them. Every fifteen minutes the direction of flow of fuel and air is reversed. In this way the air and gas is heated in one set of chambers while hot exhaust gases are heating the others. This mechanism continues for nine to twelve hours.

The molten metal is oxidised and undergoes desulphurization and dephosphorization. From time to time samples are taken for laboratory analysis to make sure the steel meets the rigid requirements test are carried out in every step in the production of steel. The metal is then tapped into ladles. The slag being lighter overflows from the ladle. The nitrogen content of the steel is low.

\section{Basic Oxygen Converter}

It most abundantly used process for procuring steel from pig iron. BOC can produce 250 tons of steel in a matter of hours. The iron is first oxidised to iron oxide by direction oxygen at the molten metal at supersonic speeds.

$$
\begin{gathered}
2[\mathrm{Fe}]+\mathrm{O}_{2}->2 \mathrm{FeO} \\
4(\mathrm{FeO})+\mathrm{O}_{2}->2 \mathrm{Fe}_{2} \mathrm{O}_{3}
\end{gathered}
$$

The iron oxide then reacts with the impurities in metal and slag.

$$
\begin{gathered}
\mathrm{FeO}+[\mathrm{Si}]->\mathrm{Fe}+\mathrm{SiO}_{2} \\
\mathrm{SiO}_{2}+2 \mathrm{FeO}->2 \mathrm{Fe} . \mathrm{SiO}_{2} \\
{[\mathrm{Mn}]+\mathrm{FeO}->\mathrm{MnO}+\mathrm{Fe}} \\
2 \mathrm{MnO}+\mathrm{SiO}_{2}->2 \mathrm{MnO} \cdot \mathrm{SiO}_{2}
\end{gathered}
$$

The iron oxide rich slag dissolves lime.

$$
2 \mathrm{MnO} \cdot \mathrm{SiO}_{2}+2 \mathrm{CaO}->2 \mathrm{CaO} \cdot \mathrm{SiO}_{2}
$$

The dephosphorisation of the metal takes place.

$$
\begin{aligned}
& 2[\mathrm{P}]+5 \mathrm{FeO}->\mathrm{P}_{2} \mathrm{O}_{5}+5 \mathrm{Fe} \\
& \mathrm{P}_{2} \mathrm{O}_{5}+4 \mathrm{CaO}->4 \mathrm{CaO} . \mathrm{P}_{2} \mathrm{O}_{5}
\end{aligned}
$$

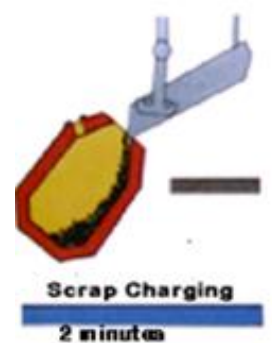

2 minutes
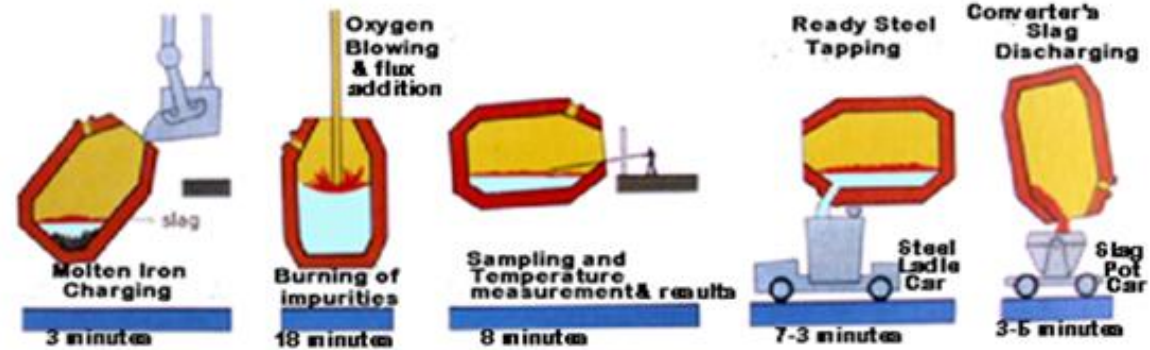

Figure 2: Steps involved in basic oxygen steelmaking 


\section{International Journal of Science and Research (IJSR) \\ ISSN (Online): 2319-7064 \\ Index Copernicus Value (2013): 6.14 | Impact Factor (2014): 5.611}

The basic oxygen converter or LD converter is a refined version of Bessemer converter where air has been replaced by oxygen. BOC reduces capital cost of plants, time of smelting and increases labour productivity.

\section{Alloying}

Molten metal from the Basic Oxygen Furnace is tapped into the ladle. The steel under goes alloying in the Ladle Metallurgical Furnace (LMF). Then the specific elements are mixed with the metal at the molten state to get the desired properties. Tungsten added to low carbon steel can withstand cold temperatures and has high resistance to pressure. A little chromium can increase the tarnishing resistance and erosion. Manganese increases strength and flexibility. Molybdenum makes steel wear resistant and extra tensile. It is a suitable replacement for tungsten in high speed steels. Vanadium increases elastic limit and tensile strength in steel without any appreciable decline in its ductility. It helps by obtaining finer grain structure.

\section{Ingot Casting}

Molten steel from Basic Oxygen Furnace or the Open Hearth Furnaceis tapped into a teeming ladle. Ingot casting process of steel making has greatly been replaced by continuous steel casting process. Only about $5 \%$ of the total steel is manufactured using this process. There are two types of teeming practices associated with ingot casting- bottom pouring and top pouring. There are three types of ingots produced based on oxygen content- killed steel ingot, semikilled steel ingot, rimming steel ingot. Killed ingots are completely deoxidised ingots. Semi-killed ingots are partially deoxidised ingots. Rimming ingots are ingots with excess oxygen.

\section{Continuous Casting of Steel}

Continuous casting solidifies a major part of the 750 million tons of steel produced every year. In this process, the ladle is positioned on top of the holding bath called a tundish to ensure continuous metal feed. Metal is transported through another shroud into a copper mold which is water cooled. This solidifies the metal. It also oscillates vertically to prevent metal from sticking to the mold walls. Hot rolling may be carried out on the metal coming out from the casting machine.

\section{Conclusion}

Steel is strong, durable and flexible. Steel's versatility is evident in engineering and in architecture. But this metal also has another quality that makes it even more dispensable- resiliency. Steel is the most recycled material on earth. It has $71 \%$ recycled rate which is approximately four times the combined amount of both aluminium and plastic. Fire, explosion may bend or break steel but seemingly nothing can destroy it. Even when steel lies in ruins it can be melted down, recast and remolded for another purpose. Its recyclability has changed the way that steel industry operates. For steel there is no self-life. No longer confined to iron ore, steel industries now use cans, guard rails or even an old dish washer as raw material. In recent years, scrap metal has drastically cut down the cost of production and reducing environmental impact.

Further advancements should be made to reduce energy consumption in steel plant. Reduction of waste production by using the waste from one industry as a raw material for another industry. For example, slag from the steel plant can be used in the cement industry as a raw material. Increasing the purity of oxygen supply can also improve productivity.Pulverized coal has become a successful practice as it increases the surface area and burns more efficiently.

\section{Future Scope}

Scientist have continued to strive for new types of steel; new combinations of elements that will give strength and shape to the twenty-first century. A new type of steel has been developed called darva glass. It is stronger than anything that has come before. Darva Glass is made by combining iron and carbon with various elements including molybdenum and boron. Darva Glass is something completely unique. It is amorphous steel. In traditional steel, atoms are packed together like crystal; they have a uniform molecular structure throughout but in amorphous steel atoms are packed randomly like glass; meaning each cross-section is different than the one before it. This jumbled atomic structure produces stronger steel. Like the invention of stainless steel nearly a century before, Darva Glass is a potential landmark. But Drava Glass has a crucial flaw; it is brittle unlike most traditional steel which has the ability to expand and contract under force. Even now with its limited capacity Darva Glass is already searching for applications. It is currently being tested at the Yucca mountain repository as a possible sealing for nuclear waste containment.

It has only been one hundred and fifty years since Henry Bessemer made the mass production of steel possible. In that short time steel has re shaped human civilization. Steel revolution has stretched the possibilities of human imagination and redefined our lives. Today at the dawn of a new century, the steel industry is responding to the demands of our future. The one constant about steel is that man drives steel to continuously evolve.

\section{Acknowledgment}

I am indebted to a number of people, who helped and motivated me to bring out this project. I would like to thank all the faculty members of the department specially Dr. Siddhartha Ray and Professor Sudipta Roy who constantly motivated and guided me.

\section{Nomenclature}

$\begin{array}{ll}\mathbf{C} & \text { Carbon } \\ \mathrm{O}_{2} & \text { Oxygen } \\ \mathrm{CO}_{2} & \text { Carbon Dioxide } \\ \mathbf{C O} & \text { Carbon Monoxide } \\ \mathbf{F e} & \text { Iron } \\ \mathrm{Fe}_{2} \mathrm{CO}_{3} & \text { Iron (III) Carbonate } \\ \mathrm{CaCO}_{3} & \text { Calcium Carbonate }\end{array}$




\section{International Journal of Science and Research (IJSR) \\ ISSN (Online): 2319-7064}

Index Copernicus Value (2013): 6.14 | Impact Factor (2014): 5.611

$\begin{array}{ll}\mathbf{C a O} & \text { Calcium Oxide } \\ \mathbf{S i} & \text { Silicon } \\ \mathrm{SiO}_{2} & \text { Silicon Dioxide } \\ \mathrm{CaSiO}_{3} & \text { Calcium Silicate } \\ \mathbf{F e O} & \text { Iron (II) Oxide } \\ \mathbf{M n} & \text { Manganese } \\ \mathbf{M n O} & \text { Manganese Oxide } \\ \mathbf{P} & \text { Phosphorus } \\ \text { LD Converter } & \text { Linz and Donawitz Converter } \\ \text { LMF } & \text { Ladle Metallurgical Furnace } \\ \text { BOC } & \text { Basic Oxygen Converter }\end{array}$

\section{References}

[1] Steel Making by A.K. Chakrabarti

[2] John L. Bray, Ferrous Processes Metallurgy, John Wiley \& Sons, 1954.

[3] G.R. Bashforth, The Manufacture of Iron and Steel, Vol. II, Indian edition, 1967.

[4] M. Peatfield and D.R.F. Spencer, Iron Making and Steel Making.

[5] Edwin J. Borrebach, Iron and Steel Engineer.

[6] William F. Hosford, Modern Steel Making, Cambridge University Press

[7] The Manufacture and Properties of Iron and Steel by Harry Huse Campbell

[8] The Manufacture and Properties of Iron and Steel by Campbell Harry Huse

[9] Iron and Steel: Their Sources, Varieties, Properties, and Manufacture by William Henry Greenwood

[10] The Manufacture and Properties of Iron and Steel Scholar's Choice Edition by Harry Huse Campbell

[11] Metallics for Steelmaking - Production and Use by Amit Chatterjee, Ramesh Singh and Banshidhar Pandey

[12] Factors confine the productivity of LD-Converter (Steel Making Department Pakistan Steel) by Aqil Khan

\section{Author Profile}

Sudipto Shekhor Mondol is in his sixth semester of Bachelor of Technology in Mechanical Engineering in Heritage Institute of Technology, Kolkata, India. His research interests lie in the field of welding technology, automotive engineering, material handling and material processing. 